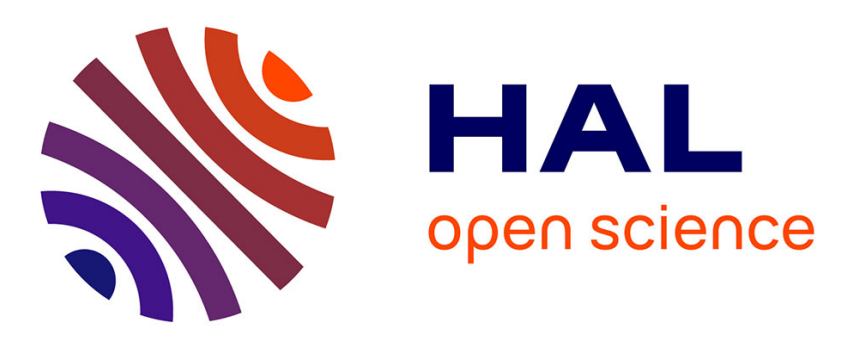

\title{
Evaluation of Plant Responses to Atmospheric Nitrogen Deposition in France Using Integrated Soil-Vegetation Models
}

Anne Probst, Carole Obeidy, Noémie Gaudio, Salim Belyazid, Jean-Claude Gégout, Didier Alard, Emmanuel Corcket, Jean-Paul Party, Thierry Gauquelin, Arnaud Mansat, et al.

\section{To cite this version:}

Anne Probst, Carole Obeidy, Noémie Gaudio, Salim Belyazid, Jean-Claude Gégout, et al.. Evaluation of Plant Responses to Atmospheric Nitrogen Deposition in France Using Integrated Soil-Vegetation Models. Critical Loads and Dynamic Risk Assessments, 25 (1ère éd.), Springer, 662 p., 2015, Environmental Pollution, 978-94-017-9508-1. 10.1007/978-94-017-9508-1_13 . hal-01153515

\section{HAL Id: hal-01153515 https://hal.science/hal-01153515}

Submitted on 5 Jun 2020

HAL is a multi-disciplinary open access archive for the deposit and dissemination of scientific research documents, whether they are published or not. The documents may come from teaching and research institutions in France or abroad, or from public or private research centers.
L'archive ouverte pluridisciplinaire HAL, est destinée au dépôt et à la diffusion de documents scientifiques de niveau recherche, publiés ou non, émanant des établissements d'enseignement et de recherche français ou étrangers, des laboratoires publics ou privés. 


\title{
Chapter 13 \\ Evaluation of Plant Responses to Atmospheric Nitrogen Deposition in France Using Integrated Soil-Vegetation Models
}

\author{
Anne Probst, Carole Obeidy, Noémie Gaudio, Salim Belyazid, Jean-Claude \\ Gégout, Didier Alard, Emmanuel Corket, Jean-Paul Party, Thierry \\ Gauquelin, Arnaud Mansat, Bengt Nihlgård, Sophie Leguédois \\ and Harald U. Sverdrup
}

\subsection{Introduction}

Anthropogenic activities have significantly increased the emissions to the atmosphere of reactive nitrogen $\left(\mathrm{Nr}\right.$, Galloway et al. 2003), mostly in its reduced $\left(\mathrm{NH}_{4}^{+}\right)$ and oxidized $\left(\mathrm{NO}_{3}^{-}\right)$form. These nitrogen species are dispersed in the atmosphere and lead to atmospheric deposition, causing an increase in the acidification and eutrophication of terrestrial ecosystems (De Schrijver et al. 2008; De Vries et al. 2007; Galloway et al. 2003; Tarrasón and Nyíri 2008). In addition to sulphur, they

\footnotetext{
A. Probst $(\triangle) \cdot$ C. Obeidy $\cdot$ N. Gaudio $\cdot$ A. Mansat $\cdot$ S. Leguédois Université de Toulouse ; INP, UPS ; EcoLab (Laboratoire Ecologie Fonctionnelle et Environnement), ENSAT, Castanet Tolosan, France e-mail: anne.probst@ensat.fr

CNRS ; EcoLab ; Castanet-Tolosan, France

S. Belyazid

Belyazid Consulting \& Communication AB, Malmö, Sweden

J.-C. Gégout

AgroParisTech, UMR 1092 INRA-AgroParistech, Laboratoire d'Etude des Ressources

Forêt-Bois (LERFoB), Nancy, France

D. Alard · E. Corket

UMR BioGeco Université Bordeaux 1, Talence, France

J.-P. Party

Sol-Conseil, Strasbourg, France

T. Gauquelin

IMBE, Aix-Marseille University, Provence, France

B. Nihlgård · H. U. Sverdrup

Department of Chemical Engineering, University of Lund, Lund, Sweden

(C) Springer Science+Business Media Dordrecht 2015

W. de Vries et al. (eds.), Critical Loads and Dynamic Risk Assessments,

Environmental Pollution 25, DOI 10.1007/978-94-017-9508-1_13
} 


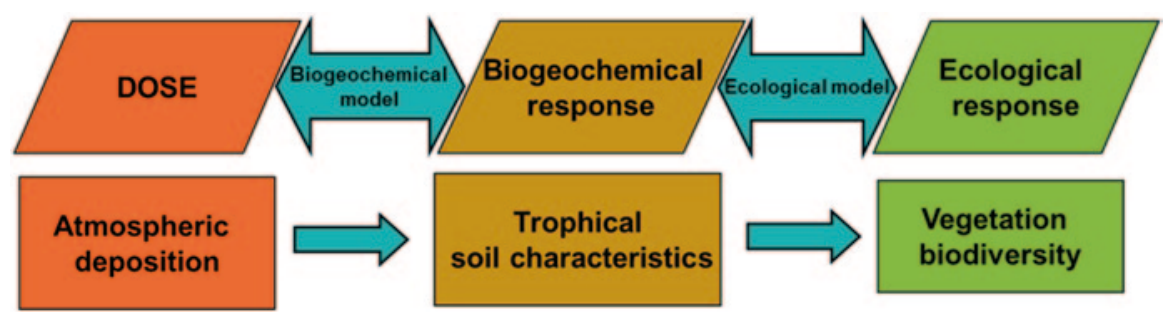

Fig. 13.1 Approach and hypothesis of the coupled biogeochemical-ecological modelling

contributed to forest dieback (Friedrich et al. 2012; Hutchinson et al. 1998; Probst et al. 1995) in eastern and northern countries over Europe in the eighties and also to the increased occurrence of nitrophilous species (Galloway et al. 2003).

Similarly to the other European countries, the semi-natural ecosystems in France are under the influence of $\mathrm{N}$ deposition due to long-range transboundary air pollution (Rogora et al. 2006; Tarrasón and Nyíri 2008), which is considered one of the main factors influencing the decrease in vegetation diversity in Europe (De Schrijver et al. 2008; De Vries et al. 2007).

Within the 1979 Convention on Long-range Transboundary Air Pollution (LRTAP), critical loads (see Chap. 1) are used as a tool to help regulate the air pollution over Europe and evaluate its impact on (forest) ecosystems (Nilsson and Grennfelt 1988; Posch 2002; Probst et al. 2008; Probst and Leguédois 2008). For nitrogen, the critical load models already developed (steady-state or dynamic geochemical models, empirical models, see Hettelingh et al. 2008) were obviously not adequate to reach objectives in terms of vegetation biodiversity conservation namely regarding ecological richness. Indeed, they took into account the influence of nitrogen deposition on vegetation only in an indirect manner by applying an assumed critical limit of $\mathrm{N}$ concentration in soil solution (allowable drainage flux; see Chap. 2) or in terms of a recommended tolerable maximal deposition based on expert advice. In France, these two kinds of approaches, i.e. the use of a biogeochemical steady-state model and empirical critical loads, lead to a major difference in critical load evaluation, which was estimated to $400 \mathrm{eq} \mathrm{ha}^{-1} \mathrm{yr}^{-1}$ for $50 \%$ of French forest ecosystems in a range of value of 200-1500 eq ha ${\mathrm{yr}^{-1}}^{-1}$ (Probst and Leguédois 2007).

Following the 25th meeting of the ICP Modelling and Mapping of the Working Group on Effects under the LRTAP Convention, a new approach was proposed based on coupling biogeochemical dynamic models with ecological integrated models (De Vries et al. 2007), in order to better take into account the impact of $\mathrm{N}$ deposition on biodiversity. This new approach was based on the hypothesis that $\mathrm{N}$ deposition will lead to a modification on biogeochemical characteristics of the soils (e.g. $\mathrm{pH}, \mathrm{C} / \mathrm{N}$ ratio). These changes in trophic conditions were supposed to cause changes in ecological response of the vegetation community (Fig. 13.1). The dose (atmospheric $\mathrm{N}$ deposition) was the origin of the biogeochemical response and as a cascade process provoked the ecological response (Belyazid et al. 2006; 
Sverdrup et al. 2007; Wallman et al. 2005). To evaluate nitrogen critical loads, dynamic models have to be run in inverse mode, i.e. it is necessary to calculate the maximum deposition that will not cause the exceedance of biogeochemical critical limits that might imply significant changes in ecological richness (Fig. 13.1). Thus it was required: (i) to define objectives of vegetation biodiversity protection; (ii) to determine the trophic limits to reach the protection objectives using an ecological model; (iii) then, using a biogeochemical model, to assess the maximum atmospheric deposition, i.e. the critical load, that led to exceedance of trophic limit conditions.

In Europe (United Kingdom, Netherlands, Switzerland, Sweden) various kinds of coupled models have been developed and tested: SMART2-SUMO-MOVE/NTM, MAGIC-SUMO-GBMOVE (see Chap. 11), BERN (Chap. 14) and ForSAFE-VEG (Belyazid et al. 2006, 2011a, b, Sverdrup et al. 2007, 2012). However, a synthesis of these pioneer work indicated that there is a need for adaptation and up-scaling of the models beyond the regions for which dose-response relationships have been parameterized, to make them generally applicable (De Vries et al. 2010). It proved challenging to extrapolate the use of these ecological models to areas for which no calibration is available, since:

- the geographical extension of vegetation species is limited;

- for a given species, the ecological response to trophic conditions could vary over the European scale territory (Diekmann and Lawesson 1999). Moreover, concerning the biogeochemical module, it is necessary to evaluate the sensitivity and the applicability at the country scale taking into account the variables and parameters needed as input.

The assessment of these possibilities is a fundamental step before applying this modelling approach at the country scale.

In this chapter, we propose as a first approach to apply the two biogeochemical models developed and used for critical load evaluation over Europe and northern America, ForSAFE (Wallman et al. 2005) and VSD+ (Bonten et al. 2009) and their coupled module VEG, on selected French ecosystems. The specific aims were:

- to test the feasibility of applying two dynamic models (ForSAFE and VSD ${ }^{+}$) on forest sites with different environmental conditions (characterized by different climatic conditions, soil physico-chemical properties such as $\mathrm{C} / \mathrm{N}$ ratio and $\mathrm{pH}$, nitrogen deposition, vegetation types...)

- to build a vegetation table composed of main forest species covering various ecological conditions typical of the very large biodiversity of French territory, to run the VEG module;

- to validate and run the coupled biogeochemical-vegetation models: VSD ${ }^{+}-\mathrm{VEG}$ and ForSAFE-VEG;

- to evaluate the variability of the model responses in term of species richness and composition predicted under current nitrogen atmospheric deposition and to discuss their sensibility. 


\subsection{Methods/Approach}

\subsubsection{Description of the Study Sites}

As the French ICP-Forests network (called RENECOFOR, the national network for long-term monitoring of forest ecosystems) has already been used for a considerable number of investigations, forest stands are very well documented (Gandois et al. 2010a, b; Hernandez et al. 2003; Party 1999). In this study, four documented forest sites (CHS41, EPC08, SP57 and PM40c) belonging to this network (Fig. 13.2 and Table 13.1) were selected to run the $\mathrm{VSD}^{+}$and ForSAFE-VEG models. The mean $\mathrm{N}$ deposition and climatic characteristics are listed in Table 13.2. The two sites from the north-eastern part of France received the highest nitrogen inputs and were dominated by spruce (EPC08) and silver fir (SP57), whereas oak and pine are the dominant species in CHS41 and PM40c, respectively. Acid soils such as cambic podzol (EPC 08), dystric cambisol (SP 57), gleyic podzol (PM40c) and stagnic luvisol (CHS41), were also addressed (Gandois et al. 2010a; Hernandez et al. 2003).

\subsubsection{Models Description and Calibration}

The two models VSD ${ }^{+}$and ForSAFE were selected since they are mechanistic models proved to be efficient in simulating the biogeochemical response to nitrogen deposition in soils. They are both linked to a VEG-module, which allows testing the forest vegetation response to nitrogen deposition (Belyazid et al. 2006, 2011a; Posch and Reinds 2009).

\subsubsection{The VSD ${ }^{+}$Model}

The $\mathrm{VSD}^{+}$model is an extension of the simpler VSD model (Posch and Reinds 2009), which was primarily developed to simulate acidification processes in soils. The extensions of $\mathrm{VSD}^{+}$concerns primarily the inclusion of the carbon $(\mathrm{C})$ and $\mathrm{N}$ cycles (Bonten et al. 2009, 2011) to make it more suitable for applications in climate change (C sequestration) and biodiversity studies. Still, $\mathrm{VSD}^{+}$is a simple model designed for applications on a (large) regional (European) scale. Thus certain processes (e.g. sulphate sorption and aluminium complexation) were neglected, and the input data requirements were kept to a minimum. For a more detailed description of the $\mathrm{VSD}^{+}$model see Chap. 8 . VSD ${ }^{+}$is a single layer model, and here a soil depth of $30 \mathrm{~cm}$ was chosen to represent the rooting depth of the vegetation.

The input data for $\mathrm{VSD}^{+}$were mainly extracted from the French RENECOFOR network, and more precisely from the four forest sites described previously, and from the French critical load database. To ensure regional application of $\mathrm{VSD}^{+}$, 


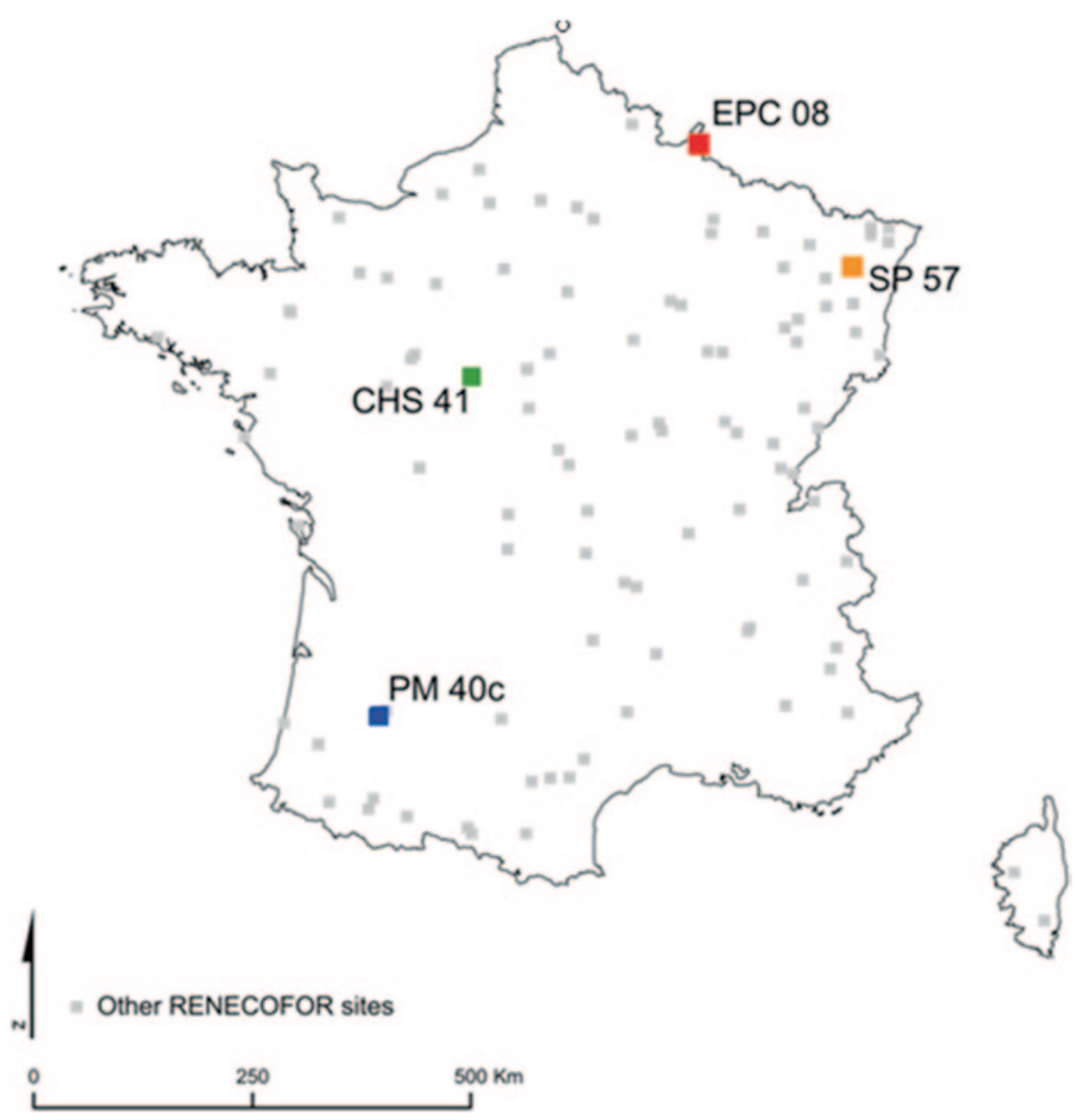

Fig. 13.2 Location of the selected RENECOFOR forest sites

EMEP deposition data $\left(\mathrm{NO}_{\mathrm{x}}, \mathrm{NH}_{\mathrm{y}}, \mathrm{S}\right)$ were used except for base cations deposition data $(\mathrm{Ca}, \mathrm{Mg}, \mathrm{K}$ and $\mathrm{Na}$ ) that came from the RENECOFOR sites.

The initial state of the model corresponded to the early state of the present-day woodland. At this stage, the initialization of the model required data for the following parameters: $\mathrm{C} / \mathrm{N}$ ratio, $\mathrm{C}$ and $\mathrm{N}$ pools, base saturation etc. Since no measured initial data were available, the model generated those data from (present-day) observations, using a Bayesian calibration method (Posch and Reinds 2009). The factors for mineralization $\left(\mathrm{rf}_{-\min }\right)$, nitrification $\left(\mathrm{rf}_{-\mathrm{nit}}\right)$ and denitrification $\left(\mathrm{rf}_{- \text {denit }}\right)$ due to moisture and temperature were computed by the MetHyd model developed with $\mathrm{VSD}^{+}$(Posch and Reinds 2010). Mean vegetation growth and litter production were considered as constant over time. Indeed, a growth function could be calculated in different ways depending on data available on biomass production and harvest. In 
Table 13.1 Input data to VSD ${ }^{+}$for the selected RENECOFOR sites. (Brêthes and Ulrich 1997)

\begin{tabular}{|c|c|c|c|c|}
\hline Parameter [unit] & CHS41 & EPC08 & SP57 & PM40c \\
\hline Period simulated & $1900-2100$ & $1960-2100$ & $1941-2100$ & $1980-2100$ \\
\hline Thickness [cm] & 0.3 & 0.3 & 0.3 & 0.3 \\
\hline $\begin{array}{l}\text { Bulk density [g } \\
\mathrm{cm}^{-3} \text { ] }\end{array}$ & 1.183 & 1.004 & 1.38 & 1.024 \\
\hline $\operatorname{Theta}^{\mathrm{a}}\left[\mathrm{m} \mathrm{m}^{-1}\right]$ & 0.3051 & 0.3776 & 0.2279 & 0.2133 \\
\hline $\mathrm{CEC}[$ meq kg-1$]$ & 39.6 & 52.22 & 26.67 & 32.56 \\
\hline $\begin{array}{l}\text { Temperature }^{\mathrm{a}} \\
{\left[{ }^{\circ} \mathrm{C}\right]}\end{array}$ & 11.05 & 8.609 & 8.307 & 12.87 \\
\hline $\begin{array}{l}\text { Percolation }{ }^{\mathrm{a}}[\mathrm{m} \\
\left.\mathrm{yr}^{-1}\right]\end{array}$ & 0.1759 & 0.586 & 0.3729 & 0.584 \\
\hline $\begin{array}{l}\text { Ca weathering } \\
{\left[\mathrm{eq} \mathrm{m}^{-3} \mathrm{yr}^{-1}\right]}\end{array}$ & 0.00774 & 0.00304 & 0.00026 & 0.00016 \\
\hline $\begin{array}{l}\text { Mg weathering } \\
{\left[\mathrm{eq} \mathrm{m}^{-3} \mathrm{yr}^{-1}\right]}\end{array}$ & 0.0018 & 0.00038 & 0.0018 & 0 \\
\hline $\begin{array}{l}\mathrm{K} \text { weathering [eq } \\
\mathrm{m}^{-3} \mathrm{yr}^{-1} \text { ] }\end{array}$ & 0.00146 & 0.00042 & 0.0013 & 0.00014 \\
\hline $\begin{array}{l}\text { Na weathering } \\
{\left[\mathrm{eq} \mathrm{m}^{-3} \mathrm{yr}^{-1}\right]}\end{array}$ & 0.00988 & 0.00766 & 0.00048 & 0.00012 \\
\hline $\begin{array}{l}\text { Bsat }{ }_{{ }_{\text {obs }}}^{\mathrm{b}}[\mathrm{eq} \\
\left.\mathrm{m}^{-3} \mathrm{yr}^{-1}\right]\end{array}$ & 0.1854 & 0.039 & 0.1348 & 0.3402 \\
\hline $\mathrm{Cppool}_{\mathrm{obs}} \mathrm{b}\left[\mathrm{g} \mathrm{m}^{-2}\right]$ & 5732 & 4937 & 2240 & 4544 \\
\hline $\mathrm{Npool}_{\mathrm{obs}} \mathrm{b}\left[\mathrm{g} \mathrm{m}^{-2}\right]$ & 299.8 & 294.4 & 119.5 & 179.5 \\
\hline $\mathrm{CNrat}_{\mathrm{obs}}{ }^{\mathrm{b}}\left[\mathrm{g} \mathrm{g}^{-1}\right]$ & 19 & 17 & 18,75 & 26 \\
\hline $\mathrm{pH}_{\mathrm{obs}}^{\mathrm{b}}$ & 4,4 & 4,1 & 4,1 & 4.45 \\
\hline $\begin{array}{l}\text { Dominant } \\
\text { species }\end{array}$ & $\begin{array}{l}\text { Quercus petraea } \\
\text { (L.) }\end{array}$ & Picea abies (L.) & $\begin{array}{l}\text { Abies alba } \\
\text { (Mill.) }\end{array}$ & $\begin{array}{l}\text { Pinus pinaster } \\
\text { (Ait.) }\end{array}$ \\
\hline
\end{tabular}

${ }^{a}$ Calculated with the MetHyd model

${ }^{\mathrm{b}}$ Measured values in 1995

Table 13.2 Open field $\mathrm{N}$ depositions (meq $\left.\mathrm{m}^{-2} \mathrm{yr}^{-1}\right)$, annual rainfall $(\mathrm{mm})$ and annual air temperature $\left({ }^{\circ} \mathrm{C}\right)$ for the selected RENECOFOR sites (mean over 1993-2008)

\begin{tabular}{l|l|l|l|l}
\hline Site code & $\begin{array}{l}\text { Mean } \mathrm{NO}_{\mathrm{x}}(\mathrm{meq} \\
\left.\mathrm{m}^{-2} \mathrm{yr}^{-1}\right)\end{array}$ & $\begin{array}{l}\text { Mean } \mathrm{NH}_{\mathrm{y}}(\mathrm{meq} \\
\left.\mathrm{m}^{-2} \mathrm{yr}^{-1}\right)\end{array}$ & $\begin{array}{l}\text { Mean annual } \\
\text { rainfall }(\mathrm{mm})\end{array}$ & $\begin{array}{l}\text { Mean air tem- } \\
\text { perature }\left({ }^{\circ} \mathrm{C}\right)\end{array}$ \\
\hline CHS41 & 17.6 & 26.1 & 766 & 11.4 \\
\hline EPC08 & 42.4 & 64.9 & 1398 & 8.8 \\
\hline PM40C & 18.2 & 22.5 & 938 & 9 \\
\hline SP57 & 36.9 & 44.2 & 1353 & 13 \\
\hline
\end{tabular}

the future, as described in the $\mathrm{VSD}^{+}$manual, a logistic growth function might be used to take into account human activities like wood uptake and harvest, as well as tree growth. Validation results of the model outputs are shown in Fig. 13.3. 

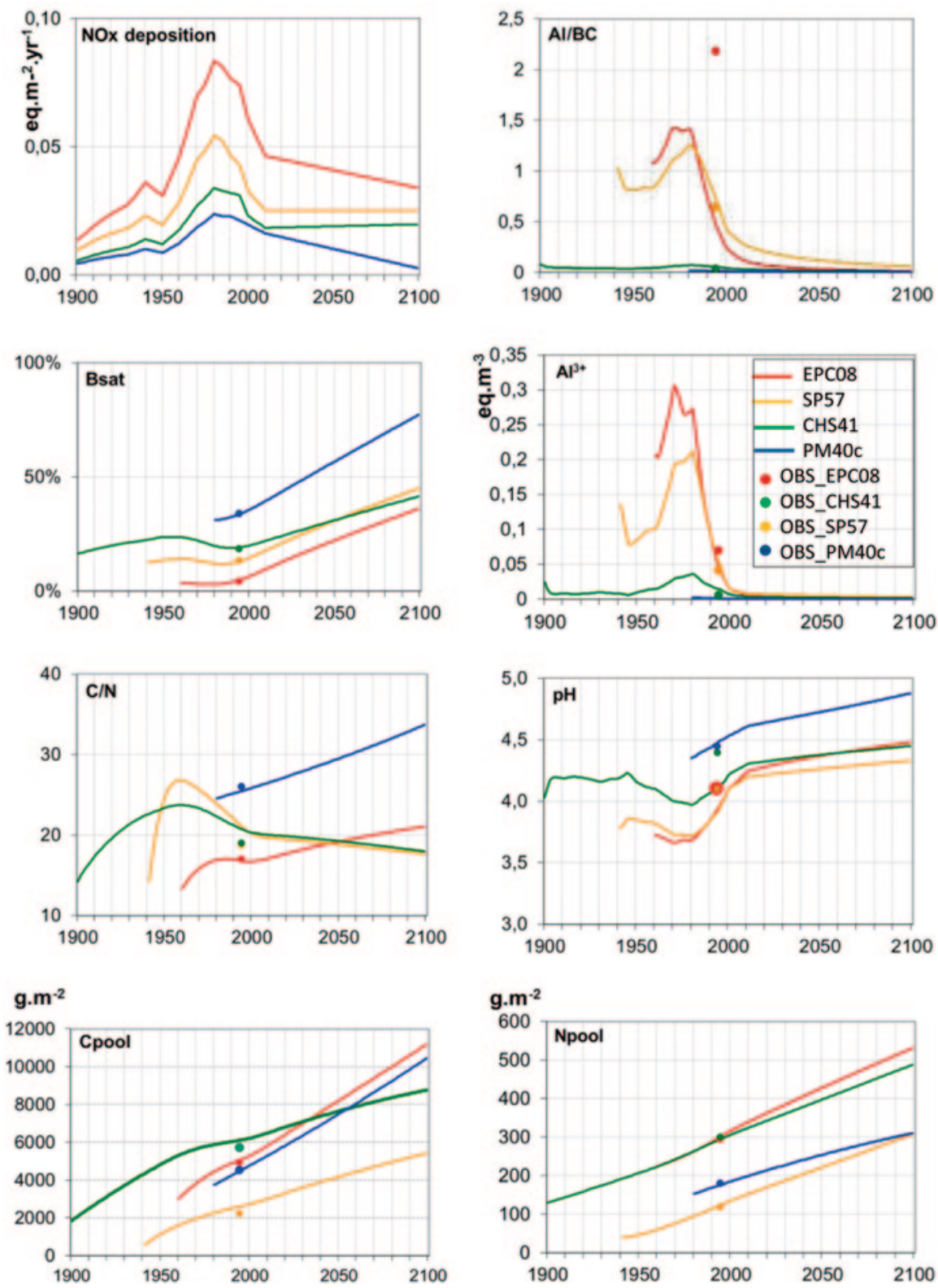

Fig. 13.3 $\mathrm{VSD}^{+}$output simulations (continuous lines) for the selected forested sites from the RENECOFOR network, and corresponding simulated EMEP nitrogen deposition. When available, the measured data (1995) are marked (circles) 


\subsubsection{The ForSAFE-VEG Model Chain}

ForSAFE: ForSAFE is a mechanistic biogeochemical model developed in Sweden (Wallman et al. 2005) and regularly improved (Belyazid et al. 2006, 2011b). The main goals of the model are to simulate (i) the cycles of carbon, nitrogen, base cations, and water in forest ecosystems; (ii) the soil acidity and aluminium mobility $\left(\mathrm{Al}^{3+}\right)$. ForSAFE is composed of four modules dedicated to specific soil and forest processes. Used at a monthly stepwise, ForSAFE simulates base cation weathering rate, soil water content, element concentrations in soil solution, flux of nitrogen and base cations accumulated in plants, mineralisation and decomposition rates of the litter, photosynthesis and vegetation growth (Belyazid 2006). Tree biomass growth is simulated by a module derived from the PnET model (Aber and Federer 1992). Photosynthesis is determined by the nitrogen content in leaves and by the amount of light reaching the site, then corrected by water and nutrients availability. The tree biomass is simulated as three tree compartments (leaves, wood and roots). This module provides information on:

- the element flux absorption to the soil chemistry module;

- the water absorption to the hydrology module; and

- the litter flux to the decomposition module.

To simulate the soil chemistry behaviour, the SAFE model has been adapted and linked to the other modules (Alveteg et al. 1995). In the chemistry module, the fluxes from weathering and from cationic exchange processes, the aluminium mobilisation, as well as the soil solution chemistry balance, are simulated. The hydrological module was adapted from the PULSE model (Lindström and Gardelin 1992) which simulates the vertical transfer of soil solution from one layer to another and the evapotranspiration. Finally, the model DECOMP was included to simulate the litter decomposition in relation with chemical and hydrological soil conditions (Wallman et al. 2006).

Input and output data in ForSAFE are more numerous than in $\mathrm{VSD}^{+}$since ForSAFE takes into account more complex processes, and also considers multiple soils layers. Consequently, this allows a better control of the simulations at each site, but on the other hand applications over more sites are limited since more input data are needed, and their availability is not so frequent at a large scale. Moreover, ForSAFE has no convenient graphic interface and basic data should be integrated. Nevertheless, some scripts were developed recently to facilitate the use of input data on several forest sites.

$V E G$ : VEG is a module simulating the composition of the plant communities in terrestrial ecosystems (Sverdrup et al. 2007). VEG reconstitutes the abundance of different kinds of understorey plants in a specific site, depending on the response of the plants to temperature and surrounding light, soil water content, soil solution $\mathrm{pH}$, and nitrogen and base cation concentrations in soil solution. Therefore, the data 
required to run VEG are related to all those parameters, which can be implemented directly in the VEG-table or by the way of ForSAFE.

ForSAFE model was run on three of the previously selected sites (except PM40c because of the lack of soil solution data). ForSAFE-VEG was then applied using the French VEG-database to perform trials on one of the forest sites (CHS41).

\subsubsection{The French Vegetation Database}

A French VEG-table (see examples in Table 13.3) was set up by a consortium of French and international experts to take into account the diversity of plant species in the French forest ecosystems. More than 230 species were added to the initial plant list set up in Sweden and Switzerland. This database is now included in a VEG European database. The extension of the species list for France was set up during a dedicated workshop with vegetation experts in October 2009. Relevant species were chosen to represent the various French forest ecosystems on the basis on expert knowledge. For each plant added to the plant list which was already documented for Sweden and Switzerland, the VEG-parameters were estimated compiling several sources of data (i.e. Rameau et al. 1989) and the new species were documented. For some parameters, the link between existing databases and the VEG-parameters needed a scale calibration (such as "nitrogen classes based on $\mathrm{C} / \mathrm{N}$ ratio", "pH" and "temperature", which were obtained from EcoPlant database (Gégout et al. 2005). The main parameters (see Table 13.3) were determined as follows:

- The delay time expressed in years, based on average generation time and lifespan, was drawn from the French flora (Rameau et al. 1989, 2008) and expert opinions.

- The classes characterizing vegetation that is promoted by enhanced nitrogen availability were based on $\mathrm{C} / \mathrm{N}$ values extracted from the EcoPlant database (Gégout et al. 2005) and adapted to the VEG classes. For the missing species of EcoPlant, the information was found in the French flora and using the Ellenberg N parameter (Bardat et al. 2004; Ellenberg et al. 1992; Ellenberg 1988; Julve 1998; Louvel et al. 2013).

- The classes characterizing vegetation whose growth is inhibited by enhanced nitrogen availability and the water and light response classes were deduced from the French flora.

- The lowest $\mathrm{pH}$ value was from the EcoPlant database and from the French flora when missing.

- The minimum temperature (the lowest annual average temperature when the plant can start taking ground) was extracted from the EcoPlant database and from the French flora when missing.

- The effective shading height was deduced from the French flora. For trees and shrubs, the height was considered only for seedling with a standard height of $0.1 \mathrm{~m}$. 


\begin{tabular}{|c|c|c|c|c|c|c|c|c|c|c|c|c|c|c|c|c|c|c|}
\hline త్ర్య & $\stackrel{8}{\circ}$ & $\begin{array}{l}8 \\
0 \\
\end{array}$ & în & î & $\begin{array}{l}\stackrel{2}{2} \\
\dot{0}\end{array}$ & 8 & $\stackrel{8}{\circ}$ & $\stackrel{0}{\circ}$ & $\begin{array}{l}\stackrel{2}{1} \\
\dot{0}\end{array}$ & $\begin{array}{l}8 \\
0 \\
0\end{array}$ & $\begin{array}{l}8 \\
\circ \\
a\end{array}$ & 8 & $\begin{array}{l}8 \\
9 \\
\end{array}$ & $\begin{array}{l}\stackrel{0}{1} \\
\dot{0}\end{array}$ & $\stackrel{?}{\stackrel{0}{0}}$ & $\stackrel{0}{0}$ & 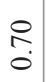 & $\stackrel{8}{8}$ \\
\hline 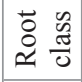 & $\stackrel{8}{8}$ & $\begin{array}{l}8 \\
0 \\
0\end{array}$ & $\begin{array}{l}8 \\
\text { i }\end{array}$ & $\stackrel{8}{8}$ & $\begin{array}{l}8 \\
i \\
i\end{array}$ & 8 & $\stackrel{8}{\circ}$ & $\begin{array}{l}8 \\
\dot{m}\end{array}$ & $\begin{array}{l}8 \\
\dot{m}\end{array}$ & $\begin{array}{l}8 \\
\dot{m}\end{array}$ & $\begin{array}{l}8 \\
\dot{r}\end{array}$ & 8 & $\begin{array}{l}8 \\
i\end{array}$ & $\begin{array}{l}8 \\
i\end{array}$ & $\begin{array}{l}8 \\
\text { i }\end{array}$ & $\begin{array}{l}8 \\
i\end{array}$ & $\underset{-}{\stackrel{8}{-}}$ & \& \\
\hline 目 & $\stackrel{\circ}{\circ}$ & $\begin{array}{l}8 \\
\vdots \\
0\end{array}$ & @) & $\stackrel{0}{0}$ & 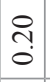 & $\stackrel{3}{0}$ & $\stackrel{\sigma}{0}$ & $\begin{array}{l}\circ \\
\stackrel{0}{0}\end{array}$ & $\begin{array}{l}0 \\
\stackrel{0}{0}\end{array}$ & $\stackrel{0}{\circ}$ & $\begin{array}{c}0 \\
\stackrel{1}{0}\end{array}$ & ō & $\begin{array}{c}0 \\
0 \\
0\end{array}$ & $\begin{array}{c}0 \\
\text { ma } \\
0\end{array}$ & $\stackrel{\circ}{\circ}$ & $\begin{array}{l}0 \\
n \\
0 \\
0\end{array}$ & $\begin{array}{c}\circ \\
0 \\
0\end{array}$ & ọ. \\
\hline 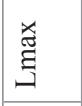 & $\begin{array}{l}\text { ஸे } \\
\infty \\
\stackrel{\sim}{0}\end{array}$ & $\begin{array}{l}\tilde{m} \\
\infty \\
\stackrel{\sim}{0}\end{array}$ & $\begin{array}{l}10 \\
0 \\
0 \\
-\end{array}$ & $\begin{array}{l}8 \\
8 \\
0 \\
1 \\
1\end{array}$ & $\begin{array}{l}8 \\
8 \\
\dot{8} \\
i \\
\end{array}$ & $\begin{array}{l}m \\
\text { m } \\
\infty \\
\stackrel{\sim}{0}\end{array}$ & $\begin{array}{l}\text { ஸे } \\
\infty \\
\stackrel{\sim}{0}\end{array}$ & $\begin{array}{l}m \\
m \\
\infty \\
\infty\end{array}$ & $\begin{array}{l}\hat{\sigma} \\
\dot{0} \\
\vec{N}\end{array}$ & $\begin{array}{l}\tilde{m} \\
\tilde{m} \\
m\end{array}$ & $\begin{array}{l}\text { ஸे } \\
\infty \\
\stackrel{n}{0}\end{array}$ & $\frac{\hat{\sigma}}{\vec{\lambda}}$ & 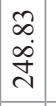 & 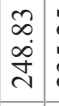 & $\begin{array}{l}\tilde{n} \\
\ddot{n} \\
\end{array}$ & $\begin{array}{l}0 \\
0 \\
\infty \\
\dot{0} \\
\tilde{d}\end{array}$ & $\begin{array}{l}\stackrel{\imath}{\hat{a}} \\
\stackrel{g}{\sim}\end{array}$ & $\begin{array}{l}\tilde{n} \\
\cdots \\
\approx \\
\end{array}$ \\
\hline 声 & $\begin{array}{l}\stackrel{0}{n} \\
\stackrel{1}{=}\end{array}$ & $\begin{array}{c}m \\
\infty \\
\infty\end{array}$ & $\begin{array}{c}m \\
\infty \\
\infty\end{array}$ & 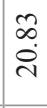 & $\begin{array}{l}8 \\
\ddot{1} \\
\beth\end{array}$ & $\stackrel{m}{\infty}$ & $\underset{\infty}{\infty}$ & $\begin{array}{l}8 \\
\text { in } \\
\text { in }\end{array}$ & $\begin{array}{c}m \\
m \\
\infty \\
\infty\end{array}$ & $\begin{array}{l}\hat{6} \\
\dot{8} \\
0\end{array}$ & $\begin{array}{l}6 \\
0 \\
8 \\
0\end{array}$ & $\begin{array}{l}0 \\
6 \\
0\end{array}$ & $\begin{array}{c}m \\
m \\
m\end{array}$ & $\begin{array}{c}m \\
m \\
m \\
m\end{array}$ & $\begin{array}{l}8 \\
\stackrel{1}{1} \\
\end{array}$ & $\begin{array}{l}m \\
m \\
m \\
m\end{array}$ & ले & $\begin{array}{l}8 \\
0 \\
i\end{array}$ \\
\hline 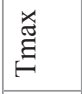 & $\begin{array}{l}8 \\
i \\
-1\end{array}$ & $\begin{array}{l}8 \\
\ddot{1} \\
-\end{array}$ & $\stackrel{8}{\Xi}$ & $\begin{array}{l}8 \\
10 \\
-1\end{array}$ & $\begin{array}{l}8 \\
\stackrel{0}{2}\end{array}$ & $\begin{array}{l}8 \\
0 \\
i\end{array}$ & $\begin{array}{l}8 \\
\infty \\
\infty \\
-\end{array}$ & $\begin{array}{l}8 \\
i \\
\end{array}$ & $\begin{array}{l}8 \\
\stackrel{1}{0} \\
\stackrel{2}{n}\end{array}$ & 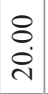 & $\begin{array}{l}8 \\
\text { ते }\end{array}$ & $\begin{array}{l}\stackrel{n}{2} \\
\stackrel{1}{\simeq}\end{array}$ & 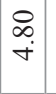 & $\begin{array}{l}\dot{\theta} \\
\dot{\theta}\end{array}$ & $\begin{array}{l}8 \\
\text { i }\end{array}$ & $\begin{array}{l}8 \\
i \\
I\end{array}$ & $\begin{array}{l}\stackrel{n}{n} \\
\stackrel{n}{n}\end{array}$ & $\stackrel{8}{\circ}$ \\
\hline$\stackrel{\circ}{\stackrel{0}{\circ}}$ & $\underset{\sim}{\stackrel{8}{2}}$ & $\underset{8}{8}$ & $\begin{array}{l}8 \\
\dot{1}\end{array}$ & $\stackrel{8}{\circ}$ & $\begin{array}{l}8 \\
\\
=\end{array}$ & $\begin{array}{l}8 \\
\infty \\
\infty\end{array}$ & $\stackrel{8}{\circ}$ & $\stackrel{8}{\circ}$ & $\begin{array}{l}8 \\
\dot{I} \\
\mathrm{I}\end{array}$ & $\begin{array}{l}\stackrel{8}{0} \\
\text { I }\end{array}$ & $\begin{array}{l}8 \\
0 \\
i \\
-\end{array}$ & $\stackrel{0}{\circ}$ & $\begin{array}{l}8 \\
i\end{array}$ & 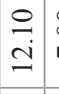 & $\underset{r}{8}$ & $\begin{array}{l}8 \\
0 \\
0\end{array}$ & $\stackrel{9}{=}$ & $\begin{array}{l}8 \\
i\end{array}$ \\
\hline 吉 & $\underset{i}{\stackrel{8}{i}}$ & $\frac{8}{8}$ & $\stackrel{8}{\stackrel{8}{i}}$ & $\underset{i}{8}$ & $\underset{8}{8}$ & 8 & $\underset{8}{8}$ & $\stackrel{8}{\stackrel{8}{+}}$ & $\begin{array}{l}8 \\
\dot{+} \\
\end{array}$ & $\begin{array}{l}\stackrel{8}{0} \\
\dot{+}\end{array}$ & $\stackrel{8}{8}$ & $\frac{2}{i}$ & $\underset{i}{\stackrel{i}{i}}$ & $\begin{array}{l}\dot{0} \\
\dot{0} \\
0\end{array}$ & $\begin{array}{l}\stackrel{0}{\sim} \\
\text { i }\end{array}$ & $\stackrel{0}{\underset{+}{+}}$ & $\stackrel{\text { กิ }}{\stackrel{0}{\varrho}}$ & $\begin{array}{l}8 \\
i\end{array}$ \\
\hline 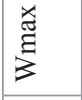 & $\begin{array}{l}\text { ర్ } \\
\stackrel{\circ}{\circ}\end{array}$ & $\underset{-}{8}$ & ڤે & ڤ్ & $\vec{n}$ & ले & ले & ले. & $\begin{array}{l}\vec{n} \\
0 \\
0\end{array}$ & $\bar{n}$ & fr. & f̊. & $\stackrel{\Im}{+}$ & $\begin{array}{l}\infty \\
\tilde{n} \\
0\end{array}$ & $\stackrel{\infty}{n}$ & 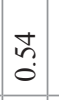 & $\stackrel{?}{\stackrel{0}{0}}$ & $\stackrel{\infty}{m}$ \\
\hline$\overbrace{}^{0}$ & थै? & \begin{tabular}{l}
8 \\
\hdashline \\
0
\end{tabular} & $\frac{n}{0}$ & $\frac{n}{0}$ & $\stackrel{n}{n}$ & $\frac{n}{0}$ & $\frac{n}{0}$ & $\frac{n}{0}$ & $\stackrel{n}{\sim}$ & $\stackrel{2}{a}$ & กิ & กิ & $\tilde{\Xi}$ & \pm & $\stackrel{ \pm}{0}$ & $\begin{array}{l}\infty \\
1 \\
0\end{array}$ & $\begin{array}{c}\infty \\
0 \\
0\end{array}$ & $\frac{ \pm}{0}$ \\
\hline$\underbrace{\Xi}_{3}$ & $\frac{n}{0}$ & 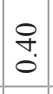 & $\stackrel{0}{0}$ & $\stackrel{2}{0}$ & $\begin{array}{l}0 \\
0 \\
0\end{array}$ & $\begin{array}{l}\stackrel{0}{0} \\
\end{array}$ & $\frac{0}{0}$ & $\begin{array}{l}\mathscr{2} \\
0 \\
0\end{array}$ & $\frac{n}{0}$ & $\frac{n}{0}$ & $\begin{array}{l}0 \\
0 \\
0\end{array}$ & $\stackrel{ \pm}{0}$ & $\stackrel{ \pm}{0}$ & $\begin{array}{l}\dot{0} \\
\dot{0} \\
\dot{0}\end{array}$ & $\stackrel{+}{0}$ & $\overrightarrow{\tilde{o}}$ & $\begin{array}{l}\text { gे. } \\
\dot{0}\end{array}$ & İ \\
\hline 苟 & $\begin{array}{l}\infty \\
\infty \\
\dot{n}\end{array}$ & $\begin{array}{c}\infty \\
\vec{i} \\
\end{array}$ & $\stackrel{\infty}{\dot{m}}$ & $\stackrel{\sim}{\sim}$ & ก̋ & $\stackrel{n}{\dot{\gamma}}$ & $\stackrel{\infty}{+}$ & 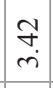 & $\stackrel{I}{\dot{T}}$ & $\begin{array}{l}\curvearrowright \\
\dot{+}\end{array}$ & $\hat{m}$ & $\hat{m}$ & $\hat{n}$ & $\begin{array}{l}+ \\
\infty \\
\dot{m}\end{array}$ & $\hat{\mathrm{n}}$ & $\begin{array}{l}\hat{O} \\
\dot{+}\end{array}$ & $\begin{array}{l}\underset{f}{+} \\
\stackrel{+}{*}\end{array}$ & $\hat{m}$ \\
\hline$\underbrace{\overparen{E}}_{\underline{y}}$ & $\stackrel{8}{\circ}$ & 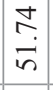 & $\stackrel{8}{\circ}$ & $\stackrel{8}{0}$ & $\begin{array}{l}8 \\
0 \\
0\end{array}$ & $\stackrel{8}{\circ}$ & $\stackrel{8}{\circ}$ & $\begin{array}{l}8 \\
0\end{array}$ & 8 & $\begin{array}{l}8 \\
0 \\
0\end{array}$ & $\begin{array}{l}8 \\
0 \\
0\end{array}$ & $\stackrel{8}{\circ}$ & \begin{tabular}{l}
8 \\
\hdashline \\
\end{tabular} & $\begin{array}{l}8 \\
\dot{0}\end{array}$ & $\stackrel{8}{\circ}$ & $\begin{array}{l}8 \\
\dot{0}\end{array}$ & $\begin{array}{l}8 \\
0 \\
0\end{array}$ & \& \\
\hline$\stackrel{+}{3}$ & $\begin{array}{l}8 \\
\text { i }\end{array}$ & $\begin{array}{l}8 \\
i \\
i\end{array}$ & $\begin{array}{l}8 \\
i \\
\end{array}$ & $\begin{array}{l}8 \\
\text { i }\end{array}$ & $\begin{array}{l}8 \\
i \\
i\end{array}$ & $\underset{8}{\stackrel{8}{i}}$ & $\stackrel{8}{8}$ & $\begin{array}{l}8 \\
i \\
i\end{array}$ & $\begin{array}{l}8 \\
i \\
i\end{array}$ & $\begin{array}{l}8 \\
i \\
i\end{array}$ & $\begin{array}{l}8 \\
i \\
\end{array}$ & $\stackrel{8}{8}$ & $\begin{array}{l}8 \\
i \\
i\end{array}$ & $\begin{array}{l}8 \\
i \\
i\end{array}$ & $\begin{array}{l}8 \\
\text { i }\end{array}$ & $\begin{array}{l}8 \\
i\end{array}$ & $\begin{array}{l}8 \\
i\end{array}$ & $\begin{array}{l}8 \\
i\end{array}$ \\
\hline$\dot{4}$ & ֻొ & $\stackrel{\overbrace{}}{0}$ & $\frac{0}{0}$ & $\stackrel{0}{0}$ & $\stackrel{0}{1}$ & $\begin{array}{l}\stackrel{0}{\circ} \\
\end{array}$ & $\frac{0}{0}$ & $\frac{0}{0}$ & $\stackrel{0}{\mathfrak{0}}$ & $\begin{array}{c}0 \\
0 \\
0\end{array}$ & $\begin{array}{c}0 \\
0 \\
0\end{array}$ & $\begin{array}{l}8 \\
\dot{m}\end{array}$ & $\begin{array}{l}8 \\
- \\
\end{array}$ & $\underset{8}{8}$ & $\stackrel{8}{8}$ & $\stackrel{8}{8}$ & $\underset{-}{\stackrel{8}{-}}$ & $\stackrel{8}{8}$ \\
\hline 声 & $\stackrel{0}{0}$ & $\frac{5}{0}$ & ?̊. & กิ & ป̦ & $\frac{1}{0}$ & $\overline{0}$ & $\stackrel{\text { กิ }}{0}$ & กิ & $\begin{array}{l}\stackrel{g}{+} \\
\dot{n} \\
\end{array}$ & $\begin{array}{l}\infty \\
\infty \\
0\end{array}$ & \pm & $\tilde{n}$ & ஸุ & $\tilde{n}$ & กี & $\underset{⿱}{\stackrel{D}{0}}$ & $\frac{⿱}{0}$ \\
\hline 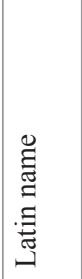 & 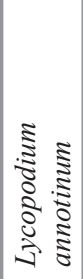 & 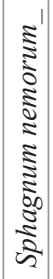 & 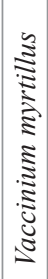 & 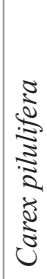 & 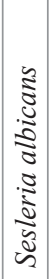 & 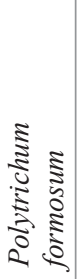 & 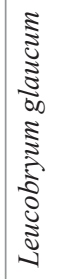 & 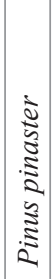 & 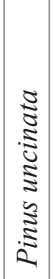 & 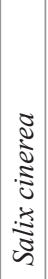 & 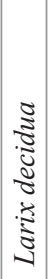 & 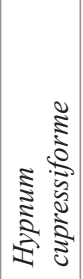 & 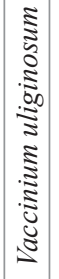 & 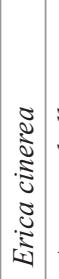 & 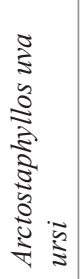 & $\mid$ & 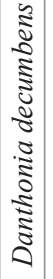 & 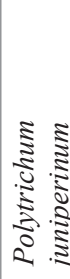 \\
\hline
\end{tabular}


- The browsing based on the palatability characteristics of the species was extracted from the literature, the pastoral floras (Boulanger et al. 2009; Bruneton 2005; Dorée 1995; Gusmeroli et al. 2007; Morellet and Guibert 1999) and expert advices.

\subsection{Results and Discussion}

\subsubsection{VSD ${ }^{+}$Output and Validation}

Figure 13.3 shows the trends in $\mathrm{C}$ and $\mathrm{N}$ pool, $\mathrm{C} / \mathrm{N}$ ratio, base saturation (Bsat), $\mathrm{Al}^{3+}, \mathrm{Al} / \mathrm{BC}$ ratio and $\mathrm{pH}$ under the influence of the evolution of nitrogen deposition over 200 years (1900-2100) depending on the early state of the present-day woodland in the sites.

The forecasted $\mathrm{C}$ and $\mathrm{N}$ pool trends in the four selected sites show a good agreement with observed values. The $\mathrm{C}$ and $\mathrm{N}$ pools were both continuously increasing, despite the decrease in $\mathrm{N}$ deposition by the nineties; nevertheless for the two sites that correspond to the youngest forests (EPC08 and PM40c), the C pool increased faster related to the rapid growth of the coniferous trees probably stimulated by the "fertilizing nitrogen input". Indeed, the highest nitrogen deposition corresponded to the period of trees plantation. This increasing pattern is in accordance with the literature (Bonten et al. 2009). However, this result could also be related to some specific inputs such as modifying factors of mineralization $\left(\mathrm{rf}_{-\min }\right)$, nitrification $\left(\mathrm{rf}_{- \text {nit }}\right)$ and denitrification $\left(\mathrm{rf}_{\text {-denit }}\right.$ ) that are known to largely influence the $\mathrm{C} / \mathrm{N}$ ratio. These parameters were poorly documented, and values used here may require further verification. Further studies are needed in order to improve these input estimates, especially by using adapted French meteorological data (e.g. missing sunshine data) to calibrate these parameters using the MetHyd model.

At all the sites, the $\mathrm{C} / \mathrm{N}$ ratio shows an increasing trend, even before the period of increasing $\mathrm{N}$ deposition at the beginning of the simulations. This may be interpreted as a significant $\mathrm{N}$ uptake for the growth of young vegetation. In PM40c, the less significant increase may be linked to the available $\mathrm{N}$ content in soil following the high $\mathrm{N}$ deposition in this period (around 1981). The $\mathrm{C} / \mathrm{N}$ ration increased in EPC08 and $\mathrm{PM} 40 \mathrm{c}$ in agreement with the significant increase in $\mathrm{C}$ pool, but the ratio decreased from 1980 in CHS41 and SP57. These latter forest sites are characterized by soils with a low nitrogen mineralization (Brêthes and Ulrich 1997).

The increasing $\mathrm{N}$ deposition led to the acidification of the four forest soils, as shown by the simulated $\mathrm{pH}$ and base saturation pattern. From 2000, $\mathrm{pH}$ and Bsat increased at the same time as $\mathrm{N}$ deposition decreases. Regarding acidification process, the impact of $\mathrm{N}$ deposition seemed more important than the influence of the vegetation and the soil type, as already shown by Moncoulon et al. (2007). With a lower N deposition level, PM40c displayed the lowest perturbations. However, the model underestimated the soil $\mathrm{pH}$ values for all sites (except for PM40c), but base saturation remained overall well predicted. 


\subsubsection{ForSAFE Output and Validation}

Before applying the ForSAFE-VEG platform, ForSAFE was validated on the selected French forest sites. The assessment of model performance consisted of the comparison between predicted and observed values (Belyazid et al. 2006, 2011a). The concentrations of $\mathrm{Na}^{+}$and $\mathrm{Cl}^{-}$( $\mu \mathrm{eq}^{-1}$ ) were used to validate the hydrological ForSAFE module since they were powerful tracers in those types of soils (Fig. 13.4). Validation was performed on about the first $20-30 \mathrm{~cm}$. A non-seasonal lag time between modelled and measured data was observed at some sites as well. The observed model behaviour discrepancy between sites might be explained by the differences in deposition levels between sites (i.e. at EPC08, $\mathrm{Na}$ and $\mathrm{Cl}$ deposition was twice that measured at $\mathrm{CH} 41$ ). Indeed, some improvements are needed in ForSAFE, including an improved representation of hydrological processes linked to water horizontal fluxes and to topography. Accounting for the mineralization of twigs and barks could further help in improving the low values that are forecasted for base cations in the soil solution (data not shown). For that purpose, a new version of ForSAFE is currently under development and validated on various sites and data.

\subsubsection{Comparison Between and Validation of ForSAFE-VEG and $V_{S D}^{+}-V E G$}

Plants from the French VEG-list (Table 13.3) have been classified into main group types (grasses, herbs, mosses, lichens and trees). As a comparison purpose, ForSAFE-VEG and VSD ${ }^{+}$-VEG were run on the CHS41 RENECOFOR site, the site with the most documented dataset. The observed and modelled data of the ground cover for the different plant groups were compared on Fig. 13.5.

To validate VEG model performance, the list of species predicted by the VEG model was compared with the species observed in the field relevés (if available). The first validation was established on site CHS41 for the year 2005. Among about one hundred species that ForSAFE was able to predict for such a site, only 23 species were observed in the site relevés: Teucrium scorodonia, Melampyrum pratense, Deschampsia flexuosa, Lonicera periclymenum, Holcus mollis, Atrichum undulatum, Polytrichum formosum were modelled and observed in this site with similar abundance. Most of them were typical plants of acidophilus oak grove characterizing this forest site. The model output was encouraging in term of ability to predict in a good way the plant response. However, about ten species observed in the field were not predicted by the model, for some of them obviously because they were note inside the VEG table. Finally, more than 80 species predicted by ForSAFE were not observed in the field relevés. Among them, some might have a good probability of occurring in the field, but others not at all because of their known temperature range. For example, some mountainous species like Cicerbita alpina, Arctostaphylos uva ursi or Atlantico-mediterranean species like Quercus suber, or 

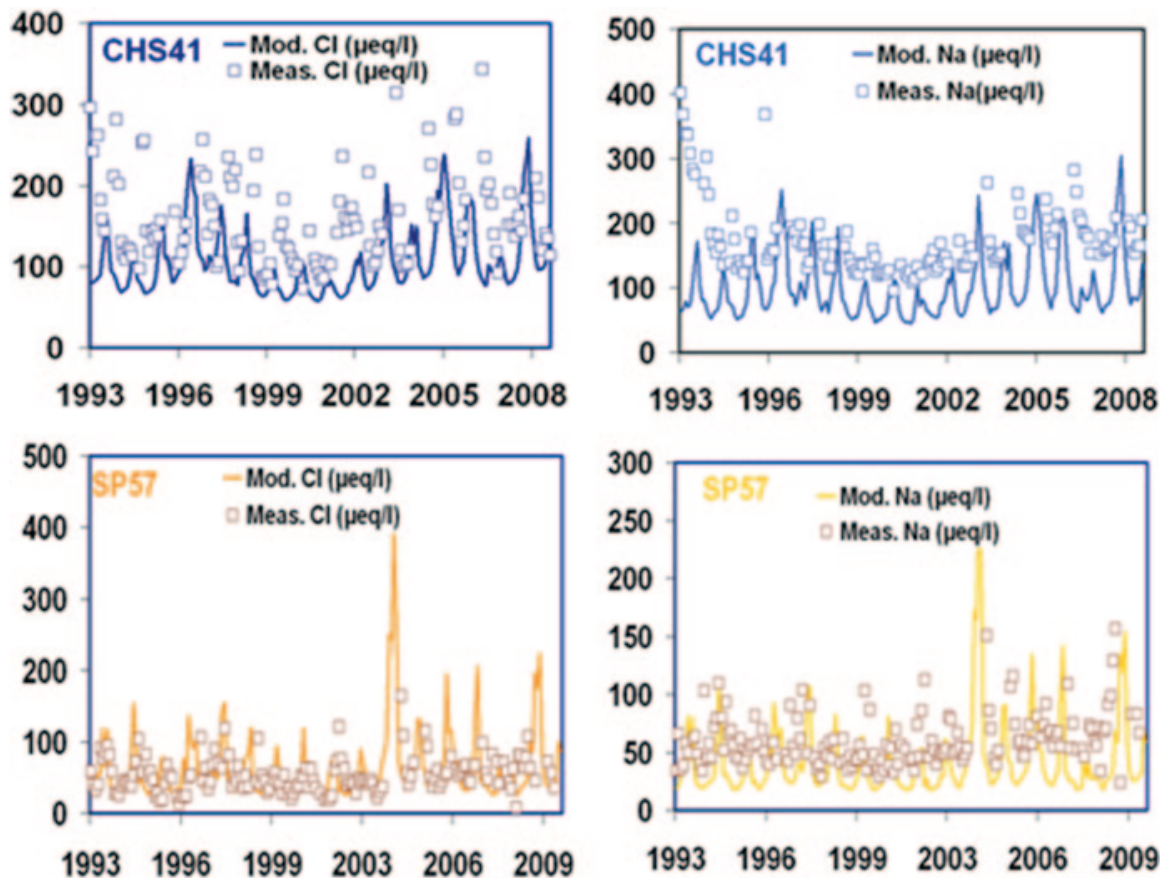

$1993 \quad 1996 \quad 19992003 \quad 2006 \quad 2009$
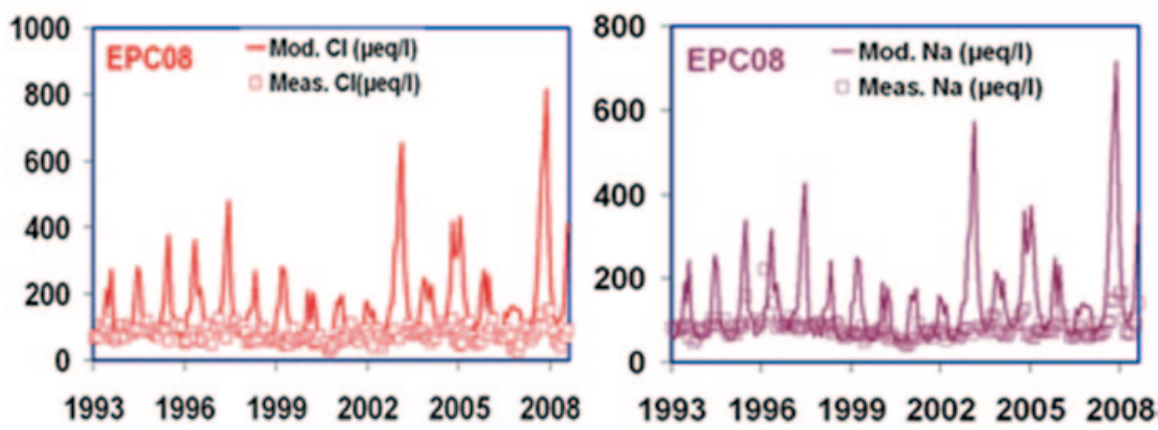

Fig. 13.4 Predicted (continuous lines) and measured (squares) $\mathrm{Na}$ and $\mathrm{Cl}$ concentrations in soil solutions between 1993 and 2009 for the selected RENECOFOR sites (CHS41, EPC08 and SP57)

more typical Mediterranean species like Pistacia sp., were mostly improbable to be found in this environmental condition. The presence of these species in the outputs indicated that improvements were needed, and this could be improved by a more thorough validation on some typical sites of the RENECOFOR network since relevés were available. This could help also to improve the parameterization of the VEG-table in order to better predict the occurrence and abundance of the species, particularly as regard to their belonging to large biogeographical regions in Europe.

Unlike ForSAFE-VEG, the VSD ${ }^{+}-\mathrm{VEG}$ model only predicted the percentage of occupancy of plant species and not the number of species that were matched by the model and observed in the site. For this reason, only the 17 species predicted 

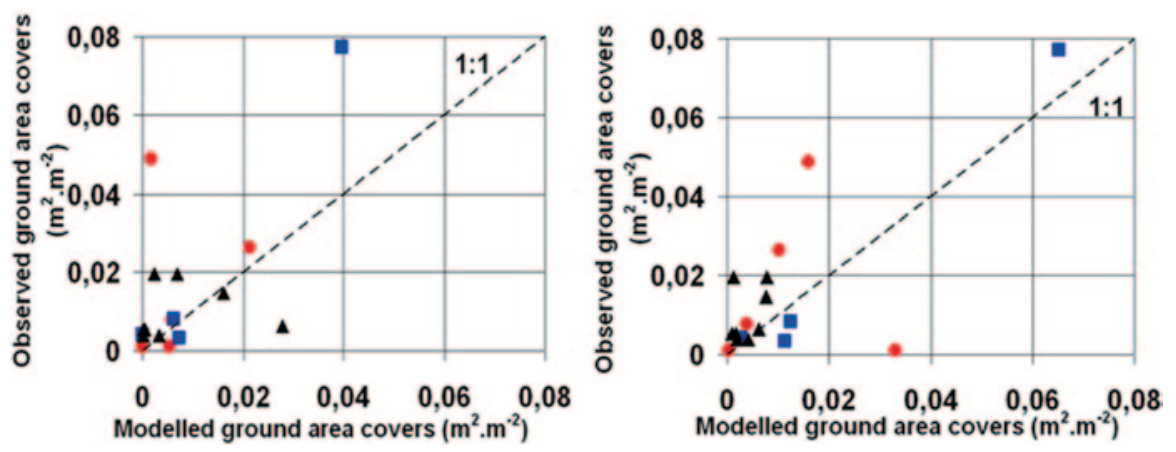

Fig. 13.5 Modelled and observed ground cover of plant groups: grasses: $\bullet$ herbs: $\mathbf{\square}$, and mosses: $\Delta$ for the site CHS41 using FORSAFE-VEG (left) and VSD+2VEG (right)

by ForSAFE were used to compare to the VSD ${ }^{+}$-VEG model outputs. The results showed (Fig. 13.5) that the two models underestimated the occurrence of certain forbs or herbs (such as Hedera helix $L$ listed in the group) and grasses (such as Holcus mollis L.). Moreover, the presence of certain mosses (such as Dicranella heteromalla Hedw.) was overestimated by ForSAFE-VEG, whereas others are underestimated by VSD ${ }^{+}$-VEG (such as Polytrichum formosum Hedw.) (Fig. 13.5).

From these trials, it could be deduced that some improvements were still needed regarding:

- $\mathrm{pH}$ and $\mathrm{C} / \mathrm{N}$, which are the main driving parameters influencing the occurrence of vegetation species (Gégout et al. 2005) for both models;

- the adjustment of some parameters in the VEG-table such as $\mathrm{pH}$ and temperature.

\subsubsection{Evaluation of Simulated Vegetation Changes by ForSAFE-VEG and VSD ${ }^{+}-V E G$}

Figure 13.6 shows the simulated changes in the occurrence of ground vegetation plant groups ( $\%$ of all simulated plant groups) as predicted by the two models from 1900 to 2100 in the CHS41 site. ForSAFE-VEG model results include variations in the computed occurrence of the plant groups. Herbs and grasses were computed to be dominant between 1920 and 1930. This could be related to the modelled behaviour of nitrogen and carbon pools and to site reforestation as mentioned in (Ponce et al. 1998). During the period between 1968 and 2002, the simulated plant response was related to the high increase in $\mathrm{N}$ deposition that occurred from 1960 to 1980 (Fig. 13.3). Particularly, the relative moss occurrence was computed to increase significantly from $4 \%$ in 1930 to $21 \%$ in 1984 . This indicated that this vegetation group is sensitive to $\mathrm{N}$ deposition. Indeed, from the literature (Armitage et al. 2011; Poikolainen et al. 2009; Xiao et al. 2010) it turns out that, mosses (Hypnum 
and Leucobyrum), grasses (Molinia and Calamagrostis), forbs or herbs (Hedera and Impatiens) and ferns (Dryopteris and Pteridium) are described most sensitive to changes in nitrogen deposition. The computed change in species occurrence was particularly obvious for Hypnum (5-10\%) from 1900 to 1980, which corresponded to the maximum of $\mathrm{N}$ deposition (Fig. 13.7). ForSAFE-VEG simulations were performed on various RENECOFOR sites showing a general increasing trend for Hypnum cover in relation to $\mathrm{NO}_{\mathrm{x}}$ deposition. However, this trend was not uniform for all sites and there is no straightforward relationship between the magnitude of $\mathrm{N}$ deposition and moss cover response. It is likely that site-specificity (e.g., biological activities, climate) is a confounding factor that needs to be addressed in more detail in the model to sufficiently reflect the monitored pattern of the given species.

On the other side for $\mathrm{VSD}^{+}$-VEG model, no significant changes were simulated in the modelled occurrence of plant groups during the same period (Fig. 13.6). This indicates that the model was less sensitive than ForSAFE-VEG to simulate tenuous vegetation changes. Nevertheless, further investigations are needed in order to compare the performance of the two models on other sites.

\subsubsection{Model Improvements Needed and Outlook}

$\mathrm{VSD}^{+}-\mathrm{VEG}$ is a simple model tailored to requirements of regional/national scale simulations of impacts to $\mathrm{N}$ deposition, but regional simulations remain to be tested and validated. Results from a first run with $\mathrm{VSD}^{+}$on the selected sites correspond rather well with reality, but we must be cautious that only one period of dataset was available for validation. This good agreement between simulated and measured soil data was encouraging, but further validation is needed. However, the following issues turned up that need to be addressed:

- the estimation of some of the key input parameters, like the "growth function" to better reflect $\mathrm{C}$ and $\mathrm{N}$ dynamics in the soil-plant system;

- meteorological inputs need to be adapted to French conditions to determine reduction functions for mineralization and (de)nitrification using the MetHyd module;

- the $\mathrm{pH}$ of French soils needs to be validated using recent soil samplings that were performed on the French ICP forest network. We must keep in mind that the underestimation of simulated soil $\mathrm{pH}$ (as observed on Fig. 13.3 particularly for the considered site CHS41) may have influenced the VSD ${ }^{+}-\mathrm{VEG}$ outputs.

A tentative comparison of simulation results between the ForSAFE-VEG and $\mathrm{VSD}^{+}$-VEG model yields the following findings (Fig. 13.6). For this, simulations were validated against times series of data. Obviously ForSAFE-VEG was more sensitive to predict vegetation changes under nitrogen deposition. But the numerous input data required to run ForSAFE-VEG might stand in the way of its application on a large country scale and, moreover, this might induce large uncertainties in model output (Wallman et al. 2005). The advantage of this modelling approach 

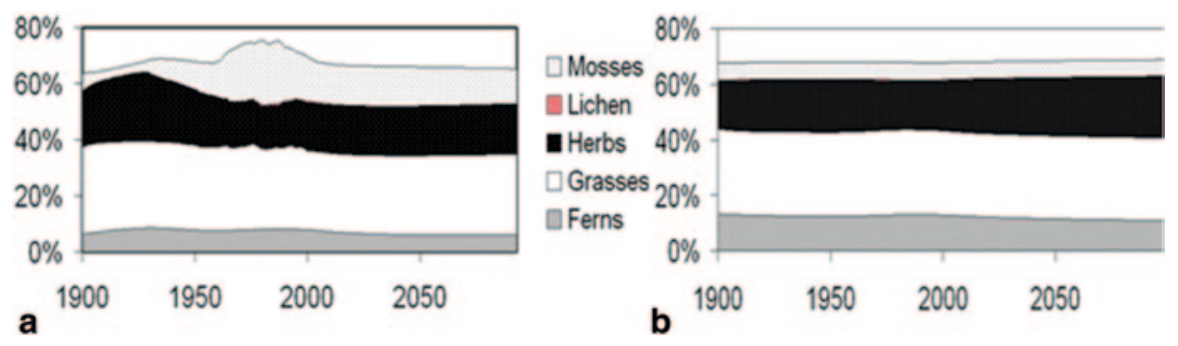

Fig. 13.6 Variation of the percentage cover of plant dominant groups at the CHS41 RENECOFOR site during the period 1900 and 2100 as simulated by (a) the ForSAFE-VEG and (b) VSD ${ }^{+}$-VEG model
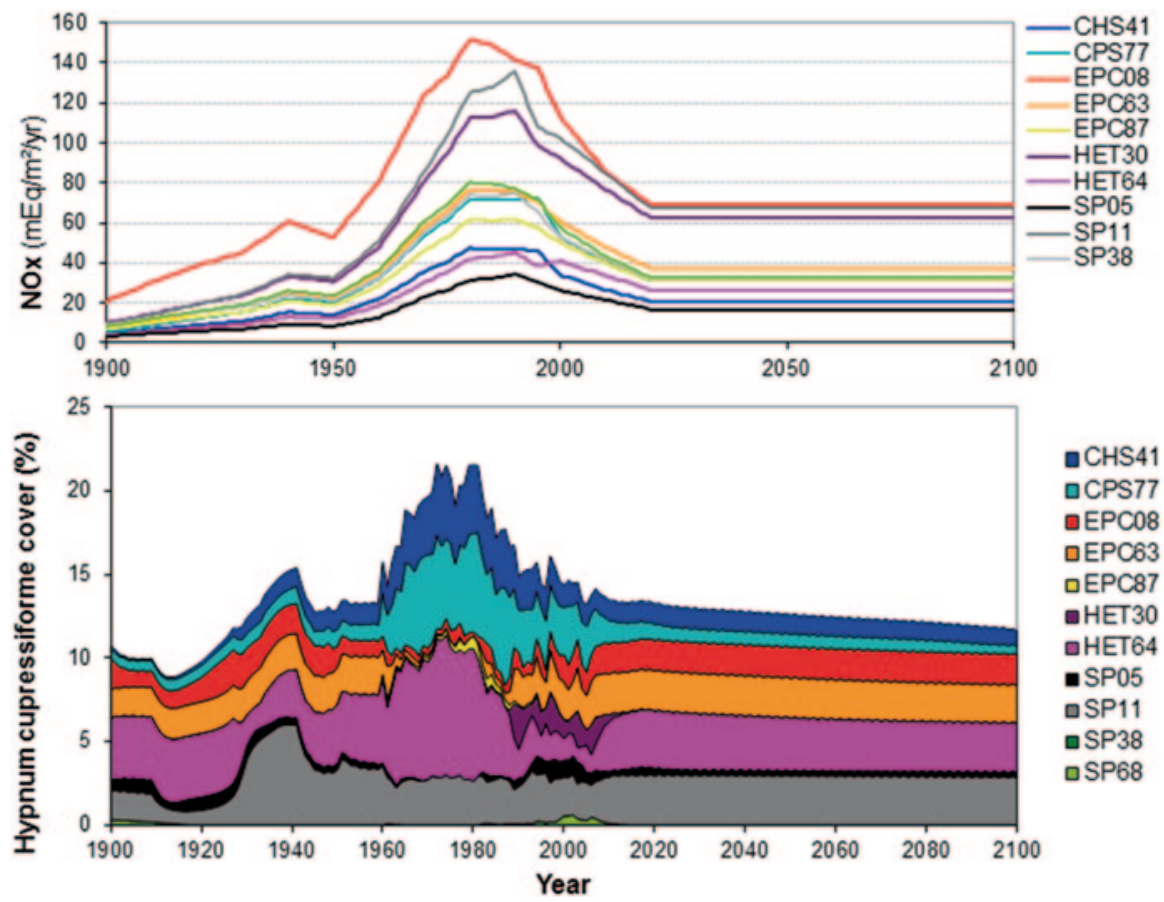

Fig. 13.7 Evolution of the EMEP modelled $\mathrm{NO}_{\mathrm{x}}$ deposition (top) and of the cover percentage of $H$. cupressiforme (bottom) as simulated by ForSAFE-VEG model at the RENECOFOR sites CHS41, EPC87, CPS77, EPC63, HET30, SP05, SP11, SP38 and HET64, between 1900 and 2100

is the long-term assessment of $\mathrm{N}$ deposition impact on the vegetation diversity. More investigations are also needed in order to improve the validation of the treatment of hydrology in ForSAFE (Belyazid et al. 2006). Indeed, validation of the nitrogen outputs in soil solution and vegetation changes must be extended to other forest sites. Moreover, management practices such as clear-cutting or thinning have 
been recently implemented in ForSAFE-VEG platform since the run on 15 French ICP-Forests sites showed that these prove an adequate footprint of the temporal variability of $\mathrm{pH}$ and nitrogen outputs. The relatively minor influence of nitrogen deposition could be explained by the strong interaction between nitrogen deposition and the canopy, as modelled by the "Canopy budget" models (Staelens et al. 2008). Thus, the amount of nitrogen reaching the soil (i.e. nitrogen having an impact on soil nitrogen characteristics) could be significantly different from the amount of nitrogen contained in bulk deposition, which was the input factor considered here. Also for some sites the influence of dry deposition could be significant and must be better taken into account in future simulations.

Recently, the VEG table has been revised at the European scale by scientific experts and some of the ecological parameters were simplified. We propose also to test a new modelling approach based on the definition of ecological and functional types (under progress). With this approach, we aim to verify the hypothesis that, the vegetative response of functional groups to site specific $\mathrm{N}$ deposition might complete current site specific findings regarding the interaction between species, in the context of environmental specific station parameters.

\section{Conclusions}

France is known for its large variety of landscape in semi-natural conditions. The ICP-Forests network has registered long time series of $\mathrm{N}$ atmospheric deposition and a large set of environmental parameters. Thanks to these data, it is possible to investigate the response of nitrogen deposition at those forest sites under various site specific environmental conditions using coupled biogeochemical and vegetation models.

These trials on ForSAFE-VEG and VSD ${ }^{+}$-VEG models and validations using measured data on RENECOFOR forest sites have allowed identifying their limitations, but they also showed that it was realistic to simulate the link between $\mathrm{N}$ deposition and under storey plant diversity. The two models have shown their ability to predict changes in soil parameters under the influence of $\mathrm{N}$ deposition. Changes in the vegetation cover according to the considered groups are better predicted by ForSAFE-VEG model chain than with $\mathrm{VDS}^{+}-\mathrm{VEG}$, since the response was more obvious for nitrogenous species like Hypnum cupressiforme. Mosses are particularly reactive and showed the highest increase in cover percentage compared to other vegetation in classes, indicating a high sensitivity to atmospheric $\mathrm{N}$ deposition. The under- or overestimation in predicting the presence of certain mosses plant cover using the two models indicated that improved calibration is needed. The ForSAFEVEG simulated change over time of the dominant ground plant groups could be related to both changes in site environmental conditions, and in particular to the influence of the maximum wet $\mathrm{N}$ deposition. However, it is likely that the simulated vegetation response to nitrogen deposition becomes even more obvious at selected sites when dry deposition is taken into account. Finally, the French VEG-table has 
been used to enlarge the European version and to increase their robustness. Ecological parameters, in addition to $\mathrm{C} / \mathrm{N}$ ratio, are currently under quantification using the EcoPlant database data (Gégout et al. 2005).

The performance of the ForSAFE-VEG and VSD ${ }^{+}-\mathrm{VEG}$ model on selected sites showed that:

- it is realistic to simulate the link between $\mathrm{N}$ deposition and vegetation diversity, and

- it is possible to improve the simulations by implementing processes and influencing factors in the geochemical models and the VEG database.

Further investigations, using other sites, are needed to compare the performance of the two models. However, the modelling of critical loads of nitrogen for forest and grasslands ecosystems based on coupled geochemical-ecological approaches is a promising way forward.

Acknowledgments We are grateful to the French partners Manuel Nicolas and Marc Lanier from the National Forest Office who helped in providing basic data from the ICP-Forest network RENECOFOR. Thanks also go to Jean-Luc Dupouey from INRA (Nancy), Vincent Boulanger (ONF) and Jean-François Picard (INRA Nancy) for providing palatability expertise and E. Bortoluzzi (EcoLab, Toulouse) for preparing the initial work on ForSAFE. We also thank Jaap Slootweg from the CCE at RIVM (Bilthoven, NL) and Luc Bonten from Alterra (Wageningen NL) for fruitful exchanges about $\mathrm{VSD}^{+}$. The French EPA (ADEME) and the Swedish EPA are particularly thanked for their financial support and work facilitation. This work was done within the PRIMEQUALPREDIT "Valeriane Project : Vulnérabilité des écosystèmes à l'azote d'origine atmosphérique. Vers un modèle de charges critiques en $\mathrm{N}$ intégrant la protection de la biodiversité végétale du territoire français" ADEME-CNRS convention $0962 \mathrm{C} 0073$.

\section{References}

Aber, J. D., \& Federer, C. A. (1992). A generalized, lumped-parameter model of photosynthesis, evapotranspiration and net primary production in temperate and boreal forest ecosystems. Oecologia, 92, 463-474.

Alveteg, M., Sverdrup, H., \& Warfvinge, P. (1995). Regional assessment of the temporal trends in soil acidification in southern Sweden, using the SAFE model. Water, Air, \& Soil Pollution, $85,2509-2514$.

Armitage, H. F., Britton, A. J., Woodin, S. J., \& van der Wal, R. (2011). Assessing the recovery potential of alpine moss-sedge heath: Reciprocal transplants along a nitrogen deposition gradient. Environmental Pollution, 159, 140-147.

Bardat, J., Bioret, F., Botineau, M., Boullet, V., Delpech, R., Géhu, J.-M., Haury, J., Lacoste, A., Rameau, J.-C., Royer, J.-M., Roux, G., \& Touffet, J. (2004). Prodrome des végétations de France. (Coll. Patrimoines naturels, 61). Paris: Muséum national d'histoire naturelle.

Belyazid, S. (2006). Dynamic Modelling of biogeochemical processes in forest ecosystems. Doctoral Thesis. Reports in Ecology and Environmental Engineering 2006:1, Sweden, Department of chemical Engineering, Lund University.

Belyazid, S., Westling, O., \& Sverdrup, H. (2006). Modelling changes in forest soil chemistry at 16 Swedish coniferous forest sites following deposition reduction. Environmental Pollution, 144, 596-609. 
Belyazid, S., Sverdrup, H., Kurz, D., \& Braun, S. (2011a). Exploring ground vegetation change for different deposition scenarios and methods for estimating critical loads or biodiversity using the ForSAFE-VEG model in Switzerland and Sweden. Water, Air, \& Soil Pollution, 216, 289-317.

Belyazid, S., Kurz, D., Braun, S., Sverdrup, H., Rihm, B., \& Hettelingh, J. P. (2011b). A dynamic modelling approach for estimating critical loads of nitrogen based on plant community changes under a changing climate. Environmental Pollution, 159, 789-801.

Bonten, L., Mol, J., \& Reinds, G. J. (2009). Dynamic modelling of effects of deposition on carbon sequestration and nitrogen availability: VSD plus and $\mathrm{C}$ and $\mathrm{N}$ dynamics $\left(\mathrm{VSD}^{+}\right)$. In J. P. Hettelingh, M. Posch, \& J. Slootweg (Eds.), Progress in the modelling of critical thresholds, impacts to plant species diversity and ecosystem services in Europe (pp. 69-73). CCE Status Report 2009.

Bonten, L., Mol-Dijkstra, J., \& Reinds, G. J. (2011). Validation of VSD ${ }^{+}$and critical loads for nutrient N. In M. Posch, J. Slootweg, \& J.-P. Hettelingh (Eds.), Modelling critical thresholds and temporal changes of geochemistry and vegetation diversity: CCE Status Report 2011 (pp. 49-52). Bilthoven, The Netherlands: RIVM Report 680359003.

Boulanger, V., Baltzinger, C., Said, S., Ballon, P., Picard, J. F., \& Dupouey, J. L. (2009). Ranking temperate woody species along a gradient of browsing by deer. Forest Ecology and Management, 258, 1397-1406.

Brêthes, A., \& Ulrich, E. (1997). RENECOFOR_Caractéristiques pédologiques des 102 peuplements du réseau. Fontainebleau, France: Office National de Forêts, Département des Recherches Techniques.

Bruneton, J. (2005). Plantes toxiques: végétaux dangereux pour l'Homme et les animaux. Ed. Médicales internationales.

De Schrijver, A., Verheyen, K., Mertens, J., Staelens, J., Wuyts, K., \& Muys, B. (2008). Nitrogen saturation and net ecosystem production. Nature, 451, E1-E1.

De Vries, W., Kros, J., Reinds, G. J., Wamelink, G. W. W., Mol, J., van Dobben, H., Bobbink, R., Emmett, B., Smart, S., Evans, C., Schlutow, A., Kraft, P., Belyazid, S., Sverdrup, H. U., van Hinsberg, A., Posch, M., \& Hettelingh, J.-P. (2007). Developments in deriving critical limits and modelling critical loads of nitrogen for terrestrial ecosystems in Europe. (Report 1382). Wageningen, the Netherlands: Alterra Wageningen UR.

De Vries, W., Wamelink, G. W. W., van Dobben, H., Kros, J., Reinds, G. J., Mol-Dijkstra, J. P., Smart, S. M., Evans, C. D., Rowe, E. C., Belyazid, S., Sverdrup, H. U., van Hinsberg, A., Posch, M., Hettelingh, J.-P., Spranger, T., \& Bobbink, R. (2010). Use of dynamic soil-vegetation models to assess impacts of nitrogen deposition on plant species composition: An overview. Ecological Applications, 20, 60-79.

Diekmann, M., \& Lawesson, J. (1999). Shifts in ecological behaviour of herbaceous forest species along a transect from northern central to North Europe. Folia Geobotanica, 34, 127-141.

Dorée, A. (1995). Flore pastorale de montagne: graminées, légumineuses et autres plantes des pâturages. Éditions Boubée.

Ellenberg, H., Jr. (1988). Eutrophierung-Veränderungen der Waldvegetation-Folgen für den RehWildverbiss und dessen Rückwirkungen auf die Vegetation. Schweiz Z Forstwes, 139, 261-282.

Ellenberg, H., Weber, H. E., Düll, R., Wirth, V., Werner, W., \& Paulißen, D. (1992). Zeigerwerte von Pflanzen in Mitteleuropa.

Friedrich, U., Von Oheimb, G., Kriebitzsch, W. U., Schlesselmann, K., Weber, M. S., \& Haerdtle, W. (2012). Nitrogen deposition increases susceptibility to drought-Experimental evidence with the perennial grass Molinia caerulea (L.) Moench. Plant Soil, 353, 59-71.

Galloway, J. N., Aber, J. D., Erisman, J. W., Seitzinger, S. P., Howarth, R. W., Cowling, E. B., \& Cosby, B. J. (2003). The nitrogen cascade. Bioscience, 53, 341-356.

Gandois, L., Probst, A., \& Dumat, C. (2010a). Modelling trace metal extractability and solubility in French forest soils by using soil properties. European Journal of Soil Science, 61, 271-286.

Gandois, L., Nicolas, M., VanderHeijden, G., \& Probst, A. (2010b). Importance of biomass net uptake for a trace metal budget in a forest stand (North-Eastern part of France). Science of The Total Environment, 408, 5870-5877. 
Gégout, J.-C., Coudun, C., Bailly, G., \& Jabiol, B. (2005). EcoPlant: A forest site database linking floristic data with soil and climate variables. Journal of Vegetation Science, 16, 257-260.

Gusmeroli, F., Della Marianna, G., Puccio, C., Corti, M., \& Maggioni, L. (2007). Indici foraggeri di specie legnose ed erbacee alpine per il bestiame caprino. Quaderno SOZOOALP, 4, 73-82.

Hernandez, L., Probst, A., Probst, J. L., \& Ulrich, E. (2003). Heavy metal distribution in some French forest soils: Evidence for atmospheric contamination. Science of The Total Environment, 312, 195-219.

Hettelingh, J. P., Posch, M., \& Slootweg, J. (2008). Critical load, dynamic modelling and impact assessment in Europe. CCE status report 2008. (RIVM Report 500090003). Bilthoven, The Netherlands: Coordination Centre for Effects, National Institute for Public Health and the Environment.

Hutchinson, T. C., Watmough, S. A., Sager, E. P. S., \& Karagatzides, J. D. (1998). Effects of excess nitrogen deposition and soil acidification on sugar maple (Acer saccharum) in Ontario, Canada: An experimental study. Canadian Journal of Forest Research, 28, 299-310.

Julve, P. (1998). Indexe écologique et chorologique de la flore de France. http://philippe.julve. pagesperso-orange.fr/catminat.htm.

Lindström, G., \& Gardelin, M. (1992). Modelling groundwater response to acidification. In P. Sanden \& P. Warfvinge (Eds.), Report from the Swedish integrated groundwater acidification project (pp. 33-36). Norrköping, Sweden: Swedish meteorological and hydrological institute. SMHI.

Louvel, J., Gaudillat, V., \& Poncet, L. (2013). EUNIS, European Nature Information System, Système d'information européen sur la nature. Classification des habitats. Traduction française. Habitats terrestres et d'eau douce. Paris: MNHN-DIREV-SPN, MEDDE.

Moncoulon, D., Probst, A., \& Martinson, L. (2007). Modeling acidification recovery on threatened ecosystems: Application to the evaluation of the Gothenburg protocol in France. Water Air \& Soil Pollution Focus, 7, 307-316.

Morellet, N., \& Guibert, B. (1999). Spatial heterogeneity of winter forest resources used by deer. Forest Ecology and Management, 123, 11-20.

Nilsson, J., \& Grennfelt, P. (1988). Critical loads for sulphur and nitrogen. Report from a Workshop held at Skokloster Sweden March 19-24 1988. Miljø rapport 1988: 15. Copenhagen Denmark Nordic Council of Ministers.

Party, J. P. (1999). Acidification des sols et des eaux de surface des écosystèmes forestiers français: facteurs, mécanismes et tendances. Strasbourg: Louis Pasteur University.

Poikolainen, J., Piispanen, J., Karhu, J., \& Kubin, E. (2009). Long-term changes in nitrogen deposition in Finland (1990-2006) monitored using the moss Hylocomium splendens. Environmental Pollution, 157, 3091-3097.

Ponce, R., Ulrich, E., \& Garnier, F. (1998). RENECOFOR—Essai de synthèse sur l'histoire des 102 peuplements du réseau. Office National des Forêts, Département des Recherches Techniques.

Posch, M. (2002). Impacts of climate change on critical loads and their exceedances in Europe. Environmental Science \& Policy, 5, 307-317.

Posch, M., \& Reinds, G. J. (2009). A very simple dynamic soil acidification model for scenario analyses and target load calculations. Environmental Modelling \& Software, 24, 329-340.

Posch, M., \& Reinds, G. J. (2010). Appendix C. MetHyd-A meteo-hydrological pre-processor for $\mathrm{VSD}^{+}$. In J. Slootweg, M. Posch, \& J. P. Hettelingh (Eds.), Progress in the modelling of critical thresholds and dynamic modelling, including impacts on vegetation in Europe. CCE Status Report 2010 (pp. 175-177).

Probst, A., \& Leguédois, S. (2007). France. In J. Slootweg, M. Posch \& J. P. Hettelingh (Eds.), European critical load and dynamic modelling and impact assessment in Europe. CCE Status Report 2007 (pp. 139-145).

Probst, A., \& Leguédois, S. (2008). France. In J. P. Hettelingh, J. Slootweg, \& M. Posch (Eds.), Critical load, dynamic modelling and impact assessment in Europe. CCE Status Report 2008 (pp. 133-140). 
Probst, A., Lelong, F., Viville, D., Durand, P., Ambroise, B., \& Fritz, B. (1995). Comparative hydrochemical behaviour and element budgets of the Aubure (Vosges Massif) and Mont-Lozère (Massif Central) spruce forested catchments. In G. Landmann \& M. Bonneau (Eds.), Forest decline and atmospheric deposition effects in the French mountains (pp. 203-225). Berlin: Springer.

Probst, A., Moncoulon, D., Leguédois, S., Party, J. P., \& Dambrine, E. (2008). Qu'a apporté le réseau pour le calcul des charges critiques en polluants atmosphériques en France? Rendez-Vous Techniques de l'ONF (hors série), 4, 77-81.

Rameau, J. C., Mansion, D., Dumé, G., Timbal, J., Lecointe, A., Dupont, P., \& Keller, R. (1989). Flore forestière française: Guide écologique illustré, Tome 1, Plaines et collines. Paris: Institut pour le développement forestier.

Rameau, J. C., Mansion, D., Dumé, G., Lecointe, A., Timbal, J., Dupont, P., \& Keller, R. (2008). Flore forestière française: Guide écologique illustré, Tome 2, Montagnes. Paris: Institut pour le développement forestier.

Rogora, M., Mosello, R., Arisci, S., Brizzio, M., Barbieri, A., Balestrini, R., Waldner, P., Schmitt, M., Stahli, M., Thimonier, A., Kalina, M., Puxbaum, H., Nickus, U., Ulrich, E., \& Probst, A. (2006). An overview of atmospheric deposition chemistry over the Alps: Present status and long-term trends. Hydrobiologia, 562, 17-40.

Staelens, J., Houle, D., de Schrijver, A., Neirynck, J., \& Verheyen, K. (2008). Calculating dry deposition and canopy exchange with the canopy budget model: Review of assumptions and application to two deciduous forests. Water, Air, \& Soil Pollution, 191, 149-169.

Sverdrup, H., Belyazid, S., Nihlgård, B., \& Ericson, L. (2007). Modelling change in ground vegetation response to acid and nitrogen pollution, climate change and forest management at in Sweden 1500-2100 A.D. Water Air \& Soil Pollution Focus, 7, 163-179.

Sverdrup, H., McDonnell, T. C., Sullivan, T. J., Nihlgård, B., Belyazid, S., Rihm, B., Porter, E., Bowman, W. D., \& Geiser, L. (2012). Testing the feasibility of using the ForSAFE-VEG model to map the critical load of nitrogen to protect plant biodiversity in the Rocky Mountains region, USA. Water, Air, \& Soil Pollution, 223, 371-387.

Tarrasón, L., \& Nyíri, Á. (2008). Transboundary acidification, eutrophication and ground level ozone in Europe in 2006. (EMEP status report). Norwegian Meteorological Institute.

Wallman, P., Svenssson, M., Sverdrup, H., \& Belyazid, S. (2005). ForSAFE-An integrated process-oriented forest model for long-term sustainability assessments. Forest Ecology and Management, 207, 19-36.

Wallman, P., Belyazid, S., Svensson, M. G. E., \& Sverdrup, H. (2006). DECOMP-A semi-mechanistic model of litter decomposition. Environmental Modelling \& Software, 21, 33-44.

Xiao, H. Y., Tang, C. G., Xiao, H. W., Liu, X. Y., \& Liu, C. Q. (2010). Stable sulphur and nitrogen isotopes of the moss Haplocladium microphyllum at urban, rural and forested sites. Atmospheric Environment, 44, 4312-4317. 